Морфологические и фенотипические особенности цитосфер, формирующихся в культуре клеток надпочечников неонатальных поросят в обычных и низкоадгезивных условиях

\author{
Е.М. Плаксина, О.С. Сидоренко, Г.А. Божок
}

Институт проблем криобиологии и криомедицины НАН Украины, г. Харьков

\title{
Morphological and Phenotypic Peculiarities of Cytospheres Forming in Adrenal Cell Cultures of Neonatal Piglets in Normal and Low Adhesive Conditions
}

\author{
E.M. Plaksina, O.S. Sidorenko, G.A. Bozhok \\ Institute for Problems of Cryobiology and Cryomedicine \\ of the National Academy of Sciences of Ukraine, Kharkov, Ukraine
}

\begin{abstract}
Ранее было установлено, что в надпочечниках человека [Santana M.M. и соавт., 2012], быка [Chung K.F. и соавт., 2009], мыши [Debatin K.M., 2013] присутствуют стволовые/прогениторные клетки, формирующие хромосферы, несущие специфические маркеры производных нервного гребня и обладающие способностью дифференцироваться в хромаффинные клетки и нейроны. Нами была предпринята попытка получения подобных клеток из надпочечников свиней. Стандартный протокол выделения и экспансии нервных стволовых клеток включает культивирование в бессывороточной среде с определенным набором ростовых факторов и использование низкоадгезивных поверхностей.
\end{abstract}

Целью представленной работы являлось сравнительное изучение морфологических и фенотипических особенностей цитосфер, формирующихся при культивировании клеток надпочечников неонатальных поросят как в обычных условиях, так и в условиях, разработанных для получения хромосфер.

Клеточную суспензию получали из надпочечных желез ферментативным методом. Клетки высевали в концентрации $1-2 \times 10^{5}$ кл/мл, культивировали при $37^{\circ} \mathrm{C}$ в атмосфере с $5 \% \mathrm{CO}_{2}$ в чашках Петри с низкоадгезивной поверхностью в среде DMEM/F 12 и добавляли 2\% B27, 20 нг/мл EGF, 20 нг/мл bFGF, 10 Ед/мл гепарина и антибиотиков (бессывороточная среда). Осуществляли замену половины среды раз в 4-5 суток. Для сравнения клетки культивировали в среде DMEM/F12 с 10\%-й фетальной телячьей сывороткой в культуральной посуде с нормальной или низкоадгезивной поверхностью. Экспрессию хромогранина А в клетках исследовали методами проточной цитофлуориметрии и иммуноцитохимии с помощью первичных поликлональных антител кролика («Abcam», Великобритания, 1:100) и вторичных антикроличьих AlexaFluor488-коньюгированных антител («Аbcam», 1:500).

Формирование флотирующих цитосфер установлено на 5-е сутки при культивировании в низкоадгезивных условиях в сывороткосодержащей и бессывороточной средах. Наблюдалось постепенное увеличение размера цитосфер в течение 28 суток культивирования. Способность цитосфер к прикреплению и дальнейшей пролиферации изучали при их переносе на подложки с адгезивной поверхностью (культуральный планшет, коллаген, фибронектин) и культивировании на среде с $10 \%$ ФТС. Различия в экспрессии хромогранина А и морфологические особенности клеток, выселяющихся из цитосфер, позволили сделать вывод о том, что состав среды и степень адгезивности поверхности являются факторами, определяющими клеточный состав и дифференцировочный потенциал цитосфер.
It was previously reported that adrenal glands of human [Santana M.M. et al., 2012], bovine [Chung K.F. et al., 2009] and mice [Debatin KM, 2013] contain stem/progenitor cells forming the chromospheres carrying specific markers of neural crest derivatives and able of differentiation into chromaffin cells and neurons. We have attempted to derive these cells from the adrenal glands of pigs. A standard protocol for isolation and expansion of neural stem cells comprises culturing in a serum-free medium with a particular set of growth factors and use of low adhesive surfaces.

The aim of the research presented was to compare morphological and phenotypic features of the cytospheres forming in cultures of new-born piglet adrenal cells both in normal conditions and in the environment specific for the obtaining chromospheres.

The cell suspension was derived from adrenal glands by enzymatic method. Cells were seeded in a concentration of $1-2 \times 10^{5}$ cells $/ \mathrm{ml}$ and cultured at $37^{\circ} \mathrm{C}$ in atmosphere with $5 \% \mathrm{CO}_{2}$ in Petri dishes with low adhesive surface in DMEM/ F12 supplemented with 2\% B27, $20 \mathrm{ng} / \mathrm{ml} \mathrm{EGF,} 20 \mathrm{ng} / \mathrm{ml}$ $\mathrm{bFGF}, 10 \mathrm{IU} / \mathrm{ml}$ heparin and antibiotics (serum-free medium). A half of the medium was replaced every 4-5 days. To make the comparison samples the cells were cultured in DMEM/ F12 with $10 \%$ fetal bovine serum in culture dishes with either normal or low adhesive surface. Expression of chromogranin $\mathrm{A}$ in cells was examined by flow cytometry and immune cytochemistry using primary polyclonal rabbit antibodies (Abcam, UK, 1: 100) and anti-rabbit secondary antibody conjugated to AlexaFluor488 (Abcam, 1:500).

Formation of floating cytospheres was found to day 5 in culture with low adhesive conditions in serum containing and serum-free media. A gradual increase in the dimensions of cytospheres was observed within 28 days of culturing. The ability of cytospheres to adhesion and subsequent proliferation was studied following their transfer to the substrates with an adhesive surface (culture plate, collagen, fibronectin) and culturing in the media supplemented with $10 \%$ FBS. The differences in chromogranin A expression and morphological characteristics of the cells migrating from cytospheres, allowed to conclude that the composition of medium and adhesive properties of surfaces were the factors determining the cell composition and differentiation potential of cytospheres. 